\title{
IMPORTANCE OF COMPUTER TECHNOLOGY IN REALIZATION OF CULTURAL AND EDUCATIONAL TASKS OF PRESCHOOL INSTITUTIONS
}

\begin{tabular}{l}
\hline \multicolumn{1}{c}{ Dr. Zvezdan } \\
\\
\hline A R T I C L E I N F O \\
Original Article \\
Received: May, 18.2016. \\
Revised: June, 06.2016. \\
Accepted: June, 11.2016. \\
doi:10.5937/IJCRSEE1601009A \\
UDK \\
004:373.21(497.115) \\
371.694 \\
\hline
\end{tabular}

\section{Keywords:}

preschoolteachers, preschool instituction, computer, educational facilities.

\begin{abstract}
A B S T R A C T
The rapid scientific and technological development imposes numerous changes in all spheres of life and work. In such circumstances, a computer has become a part of all aspects of life: economy, education, free time, family. Since children in contemporary society increasingly acquire knowledge before the school age, the question is how to prepare them for the world in which we live, bearing in mind how significantly different it is from the world in which the previous generations grew up.

The research was aimed at examining the attitudes of preschool teachers about the importance of computers in the realization of educational activities in preschool institutions. The study included 54 teachers from Kosovo and Metohija: Kosovska Mitrovica, Donja Gušterica and Ropotovo. The research results indicate that digital technology is a very important and a useful didactic tool in the realization of educational activities in preschool institutions and that preschool teachers have the required competence to implement the technology. However, they are not satisfied with the quality of their ICT education and training during their studies; they also feel that their institutions do not provide adequate working conditions for the use of computers in the realization of educational tasks.
\end{abstract}

\section{INTRODUCTION}

One of the most important tasks of educational work at the present stage of social development is improving the efficacy of the existing means, methods, and forms of work, as well as finding new and more effecient ones. In order to complete the set tasks, modern technology found its way to preschool institutions; it is gradually implemented with the content being adapted to different age groups, levels, and forms of education. Realization of the preschool program includes creating the conditions for the use of computers in their work with children; in relation to the mentioned age

Corresponding Author

Dr. Zvezdan Arsić, Faculty of Philosophy, Kosovska Mitrovica,E-mail: zvezdanars@gmail.com

\section{(i)}

This work is licensed under a Creative Commons Attribution 4.0 International license. The article is published with Open Access at www.ijcrsee.com there is an essential specificity in the planning and delivery of educational activities.

Unlike the primary education, activities with preschool children are organized through games, which encourage the development of their total potential, preparing them for school, as well as life in general, which is one more reason that computersshould have a place in their playing and learning (KopasVukašinović, 2007, pp. 774). The possibility of introducing new media and technologies in the educational work with children of preschool age is indicated by the results of various studieswhich show "that at the age of three years and 7 months, children are alreadyable to learn to independently use a computer, in degree to which it meets their needs, while early two-year-olds can "handle a computer mouse" (Andevski, Arsenijević, 2011, pp. 26). In the light of the problem which is the primary focus of this paper, an interesting study conducted by the Association of preschool teachers of Belgrade in 2007, which examined 1,008 parents of children ages 3 to 7 , showed 
that $79 \%$ of the children has access to acomputer. In addition, children aged 3 to 6 years old on average spend two hours ata computerorTV, while the children of 6 or more spend exponentially more time in front of the screen (Anđelković, 2008a, pp. 64-71).

The use of computers in preschool period is associated with cognitive and social development of children. Children who have access to a computer perform better in preparation, ie. school readiness, indicating that access to the computer during the preschool period is related to the development of preschool concepts and ideas (Veličković, 2014, pp. 377). Computer access in preschool institutions helps children to overcome the differences that result from not having access to it at home and gives them a fair chance to participate in the group activities and closes the gap that exists between the children with and without a computer (Creaseyetal., 1998. pp. 118).

During the realization of educational tasks in preschool institutions, particular attention should be placed on the developmental milestones and specifities of the age.The development of children under three years of age is characterized by specific physical, perceptual, and sensory cognition of their body and the world around them. During this period the children, above all, learn to walk, run, speak, and enter into social relationships with other children and people in their immediate and distant environment; they experience the world mainly through their senses - eyesight, hearing, taste, smell, and touch. The information technology can, in a specific and simplified way, be a part of a child's experience, however, its impact on this age group is not significant and it does not represent the real needs of a child (Anđelković, 2008b, pp.78). Nonetheless, after the age of three, children are able to learn how to independently use a computer. Therefore, the implementation of information technology in the educational work in this period satisfies their needs and interests, as confirmed by the results of the above study.

In addition to the expressed views, observations, analysis of empirical research results, and conclusions in favor of the implementation of ICT, the technology can also teach children to think and can be used enhance the quality of the educational system at any level. On the other hand, some authors express "apprehension" that the use of a computer can lead to poorer mastery of elementary operations such as reading, writing, and arithmetic.Furthermore, there are fears that a child who spends too much time at acomputer, can become isolated and deprived of social relationships that are necessary for their overall development.

The most common issues raised in relation to computer use are:

- health threats,

- possible addiction,

- changes of child's interests,

- threat to the acquisition of basic operational skills (preschool and school),

- threatens the computer preschool teacher and teachers,

- decreased socialization and possible dehumanization of the educational process,

- threat to the preschoolteachers and their role,

- empirical evidence of better and deeper learning,

- learning to think by using a computer,

- influence on the the difference gap between the school children (Rečicki, Girtner, 2002).

Based on the results obtained by surveying the parents about the possible negative and positive consequences of the use of computers by children in the preschool period $\mathrm{Lj}$. Žiropađa (Žiropađa, 2007, pp. 72) concludes that parents are most concerned with the four negative consequences:

- deviation from the classes and school activities,

- danger to physical health,

- encouraging children to aggressive behavior and

- fear that children who use a computer forget the basic skills such as writing and arithmetic.

As for the positive outcomes of computer use, parents most oftenlymention:

- English language competences,

- development of concentration andspeed of observations in children,

- reinforcement of curiosity and

- promotion of sociability and readiness for cooperation (Žiropađa, 2007, pp. 73).

Representatives of modern pedagogical thought believe that the use of computers in the realization of educational tasksat an early age embodies the right of a child to acquire rich and diverse experiences through information and communication technologies.However, despite the contention that computer education is becoming as important as basic 
literacy, there are many obstacles to making it a part of the educational system atany level. In addition to the "anguish" of the negative consequences that the inadequate and inappropriate computer use can cause in children, there are many other reasons that make its application in educational work with childrendifficult. The most important among them are as follows:

- non-functional space in which educational activities with children are carried out,

- insufficient number of modern teaching aids,

- reluctance to give up old habits, as well as fear of new challenges and demands, hence the hesitation in more active implementation of the proclaimed goals and tasks,

- a large number of children in the group,

- insufficient training of educators in the field of IT technologies.

The realization of educational tasks in preschool institutions by usingcomputers sets a preschool educator before some very specific requirements, ranging from the preparation of activities through their participation in these activities by monitoring children's accomplishments. Those requirements include computer literacy, educators' insight into the quality and characteristics of the existing software for preschool children,as well as motivation and interest of preschool educators to deliver the activities by means of IT. All this requires a specific training program for preschool educators:

- basic computer skills,

- specific IT skills that are important for working with children,

- basic theoretical knowledge about the possibilities of IT application in working with children, as well as the specific areas of child development it can promote,

- the dangers of its inadequate implementation (Anđelković, 2008b, pp. 108).

\section{MATERIALS AND METHODS}

\subsection{The subject of research}

The essence of the ICT application in the educational work is aimed at overcoming the traditional understanding of the organization and delivery of educational activities at all levels of the educational system, including the preschool education. Taking into account the study and research findings presented in the previous section of the paper, it is authors'intention to point out the importance of application of modern information and communication technologies, especially computer use in the delivery and attainment of educational tasks in preschool institutions. Further attention is payed to specific problems that arise in this area.For this reason, the subject of this research is theoretical and practical study of nature and the typical problems of computer use in realization of educational tasks in preschool institutions.

\subsection{The aim and objectives of research}

The aim of the research is empirical and non-experimental study and analysis of the attitudes of preschool educators about the effects of their computer use, their ability to use modern means of information transfer and the conditions in which educational tasks in preschool institutions are realized.

From such a specific research aim, specific research tasks to be implemented in the process are derived:

- examine the attitudes of teachers about the importance and role of computer applications in work with preschool children,

- examine the attitudes of teachers about personal competences to use modern methods of transmission of information (computer) in work with preschool children,

- examine the attitudes of teachers about learning competencies for use of computers during the initial training;

- examine the attitudes of preschool educators about the conditions in which they organize and implement the educational process in the institutions.

\subsection{Research hypotheses}

The general hypothesis is:

- computer technology can be an extremely important and useful didactic tool in the delivery of the educational activities and attainment of the educational tasks. Furthermore, if 
properly implemented, it can significantly contribute to the development of children's skills and advancement of educational work.

Specific hypotheses are:

- It is assumed that preschool educators believe that computers have a positive impact in working with preschool children;

- It is assumed that preschool educators are considered to possess sufficient competence to use personal computers in their work with children of preschool age,

- It is assumed that preschool educators consider their initial education instrumental in achieving the necessary competencies for the successful use of computers in working with preschool children;

- It is assumed that preschool educators believe that the institutions in which they work are adequately equipped.

\subsection{The research sample}

The study usedan intentional sample of 54 educators from preschool institutions in Kosovo and Metohija - Kosovka Mitrovica („Danica Jaramaz“), Donja Gušterica (,Sunce") and Ropotovo („Pčelica Maja“). Since this is an intentional selection, we do not consider it representative of the whole population. However, considering the selectioncriteria (results achieved, personnel, space and technical resources), we believe that we have achieved an approximate representation of the sample for the area in which the survey was conducted. The research sample consists of preschool educators of different qualifications, age, work experience, and the different ages of theirstudents.

Table 1. Structure of the sample in relation to the qualifications of the respondents

\begin{tabular}{lcc}
\hline $\begin{array}{c}\text { Professional } \\
\text { qualifications }\end{array}$ & Frequencies & Percentages \\
\hline High School & 9 & 16,7 \\
\hline Two year college & 26 & 48,1 \\
\hline Three year college & 19 & 35,2 \\
\hline
\end{tabular}

Table 2. Sample structure of preschool educatiors in relation to the work experience

\begin{tabular}{lcc}
\hline Years of service & Frequencies & Percentages \\
\hline From 0 to 10 years & 20 & 37,0 \\
\hline From 10 to 25 years & 18 & 33,3 \\
\hline Over 25 years & 16 & 29,6 \\
\hline
\end{tabular}

Table 3. Structure of the sample in relation to the age of the children they are working with

\begin{tabular}{lcc}
\hline \multicolumn{1}{c}{ Age } & Frequencies & Percentages \\
\hline $\begin{array}{l}\text { Younger } \\
\text { preschoolers }\end{array}$ & 24 & 44,4 \\
\hline $\begin{array}{l}\text { Medium pre- } \\
\text { school age }\end{array}$ & 15 & 27,8 \\
\hline $\begin{array}{l}\text { Older } \\
\text { preschoolers }\end{array}$ & 15 & 27,8 \\
\hline
\end{tabular}

Table 4. Structure of the sample in relation to age of respondents

\begin{tabular}{ccc}
\hline Minimum & Maximum & $\begin{array}{c}\text { The } \\
\text { arithmetic } \\
\text { mean }\end{array}$ \\
\hline 25,00 & 53,00 & 41,43 \\
\hline
\end{tabular}

\subsection{Methods, techniques, research instruments}

The study applied a descriptive method to describe the process, events and relations between the pedagogical phenomena which are the subject of research.The basic technique for data collection was a surveywhereby the instrument used special scales. The assessment scale was specifically designed for this study and each item is considered as a scale of attitude with organized categories. Categories range from a completely negative attitude (1.Strongly disagree), through the neutral (2.Partly agree), to a completely positive attitude (3.Strongly agree). The scale is divided into four factors, each factor representing one of the research tasks. The first factor relates to the positive impact of the use of modern information and communication technology on the behavior and personality of students. The second factor relates to the attitudes of preschool educatorstowards the necessary competences for personal use of computers in the realization of educational tasks in preschool institu- 
tions. The third factor relates to the attitudes of teachers on the quality of IT training during their initial education. Finally, the fourth factor relates to the attitudes ontechnical resources of the institutions wherethey work.

\subsection{Statistical data processing}

Specialized software for statistical data processing (SPSS for Windows 19) was used in the study. Moreover, the statistical methods used were:

- Descriptive statistics (frequencies and percentages)

- Arithmetic mean (AM) and Standard deviation (SD)

- Analysis of variance (ANOVA)

\section{RESULTS}

Use of computers in the educational work with children of preschool age is of a relatively recent date, hence the changes occurring in this area are very intense and sometimes take and unexpected turn.Therefore, it is very important for teachers in preschool institutions to recognize the importance of continuous monitoring of the impact and effects of ICT on the development and learning of children, and always look for better and more efficient ways to nurture and enrichthe experiences that children inevitably acquire in our information society.

Responses to the general hypothesis of the research were obtained by dividing the hypothesis into several more specific hypotheses and grouping the responses accordingly for better understanding. The first specific hypothesis was tested by measuring the degree of expressiveness of the positive impact of computer use by comparing the average scores (ANOVA).Analysis of the results (Table no. 5) shows that computers have a positive impact on the work with preschool children, as teachers largely believe that the application of computers enhances working habitsencourages children to acquire new knowledge.
Table 5. Expressiveness of attitudeon the positive impact of computers in working with preschool children

\begin{tabular}{lcccc}
\hline \multicolumn{1}{c}{ Factor 1 } & Minimum & Maximum & AM & SD \\
\hline $\begin{array}{l}\text { The positive impact } \\
\text { of computers }\end{array}$ & 6,00 & 15,00 & 11,81 & 2,40 \\
\hline $\begin{array}{l}\text { Question 1 - } \\
\text { encourages working } \\
\text { mood }\end{array}$ & 2,00 & 3,00 & 2,67 &, 48 \\
\hline $\begin{array}{l}\text { Question 2 - } \\
\text { encourages the } \\
\text { development of } \\
\text { thinking }\end{array}$ & 1,00 & 3,00 & 2,37 &, 73 \\
\hline $\begin{array}{l}\text { Question 3 - } \\
\text { encourages the } \\
\text { development of } \\
\begin{array}{l}\text { autonomy in } \\
\text { children }\end{array}\end{array}$ & 1,00 & 3,00 & 1,94 &, 83 \\
\hline $\begin{array}{l}\text { Question 4 - } \\
\text { encourages logical } \\
\text { reasoning }\end{array}$ & 1,00 & 3,00 & 2,13 &, 67 \\
\hline $\begin{array}{l}\text { Question 5 - } \\
\text { encourages the } \\
\text { acquisition of new } \\
\text { knowledge }\end{array}$ & 1,00 & 3,00 & 2,70 &, 54 \\
\hline
\end{tabular}

The second specific hypothesis was tested by measuring the degree of expressiveness of personal competencies of teachers by comparing the average scores (ANOVA). Analysis of the results (Table 6) shows that preschool educators largely believe that they have a good command of modern operating systems, as well as a good grasp of the right way to use the web and different software for the planning and delivery of activities in preschool institutions.

Table 6. Expressiveness ofattitude in personal competencies of teachers

\begin{tabular}{lcccc}
\hline \multicolumn{1}{c}{ Factor 2 } & Minimum & Maximum & AM & SD \\
\hline $\begin{array}{l}\text { Personal } \\
\text { competence of } \\
\text { preschool } \\
\text { educators }\end{array}$ & 4,00 & 12,00 & 9,54 & 2,34 \\
\hline $\begin{array}{l}\text { Question 6 - Uses } \\
\text { modern operating } \\
\text { system }\end{array}$ & 1,00 & 3,00 & 2,57 & 0,57 \\
\hline $\begin{array}{l}\text { Question 7 - Uses } \\
\text { the web and other } \\
\text { applications }\end{array}$ & 1,00 & 3,00 & 2,41 & 0,74 \\
\hline $\begin{array}{l}\text { Question 8 - } \\
\text { Informs and } \\
\text { instruct a child on } \\
\text { how to use a } \\
\text { computer }\end{array}$ & 1,00 & 3,00 & 2,19 & 0,78 \\
\hline $\begin{array}{l}\text { Question 9 - } \\
\begin{array}{l}\text { There are } \\
\text { adequate } \\
\text { competence for } \\
\text { innovative } \\
\text { information } \\
\text { management }\end{array}\end{array}$ & 1,00 & & & \\
\hline
\end{tabular}


The third specific hypothesis was tested by measuring the degree of expressiveness of the quality of IT training thepreschool educatorshad during their initial education by comparing the average scores (ANOVA). The result ananlysis (Table no. 7) shows that preschool educators largely believe that the curriculum of higher education institutions that they have completeddoes not cater to the demands of IT education imposed by the modern information society and that it is not in accordance with the basic characteristics of the development of modern society.

Table 7. Expressiveness of attitude on the quality of IT education during initial education

\begin{tabular}{lcccc}
\hline \multicolumn{1}{c}{ Factor 3 } & Minimum & Maximum & AM & SD \\
\hline The quality of IT education & 27,00 & 23,00 & 25,61 & 1,00 \\
\hline $\begin{array}{l}\text { Question 10 - Curriculum of IT training during initial } \\
\text { education is adapted to the requirements of the } \\
\text { information society }\end{array}$ & 3,00 & 1,00 & 2,89 & 0,42 \\
\hline $\begin{array}{l}\text { Question 11 - Curriculum of IT training during initial } \\
\text { education is contemporary and promoted }\end{array}$ & 3,00 & 1,00 & 1,93 & 0,64 \\
\hline $\begin{array}{l}\text { Question 12 - Curriculum of IT training program during } \\
\text { the initial education is in line with the characteristics of } \\
\text { the development of society }\end{array}$ & 3,00 & 2,00 & 2,80 & 0,41 \\
\hline $\begin{array}{l}\text { Question 13 - Curriculum of IT and computer education } \\
\text { program has been designed in accordance with the } \\
\text { confirmed positive examples }\end{array}$ & 3,00 & 1,00 & 1,65 & 0,55 \\
\hline
\end{tabular}

Examination of the fourth special hypothesis was done by measuring the degree of expressiveness of the technical resources ofthe surveyed institution by comparing the average scores (ANOVA).Analysis of the results (Table no. 8) shows that preschool educators largely believe that the institutions in which they work cannot provide the necessary con- ditions for the realization of educational tasks by way of ICT, because they do not have adequate information and communication technology. Furthermore, neither educators nor the students have access to computers. In addition, there is no required continuity in training the teachers to use coputers in their professional work. Plus, the internet access is very limited.

Table 8. Expressiveness of attitude on the equipment of the institution where the preschool educatorsworks

\begin{tabular}{lcccc}
\hline \multicolumn{1}{c}{ Factor 4 } & Minimum & Maximum & AM & SD \\
\hline Equipped institutions & 5,00 & 13,00 & 5,78 & 1,30 \\
\hline Question 14 - Owns modern computers & 1,00 & 3,00 & 1,30 & 0,54 \\
\hline $\begin{array}{l}\text { Question 15 - Access to a computer for preschool } \\
\text { educators }\end{array}$ & 1,00 & 2,00 & 1,09 & 0,29 \\
\hline Question 16 - Allows the child to access to the computer & 1,00 & 2,00 & 1,04 & 0,19 \\
\hline Question 17 - Allows education and training & 1,00 & 3,00 & 1,24 & 0,58 \\
\hline Question 18 - It has a high-quality internet connection & 1,00 & 3,00 & 1,11 & 0,42 \\
\hline
\end{tabular}

\section{DISCUSSION AND CONCLUSION}

Responses to the first group of research tasks indicate that the main hypothesis was confirmed that the organization of educational activities and the implementation of educational tasks in preschool institution are largely more effective with the help of computer technology. A computer is an extremely important and useful didactic tool that, if properly implemented, significantly contributes to the development of children skills and advancement of educational work. In addition, the first specific hypothesis confirms this general conclusion because teachers believe that the implementation of computer technology has a positive impact on their work with preschool children, especially in encouraging working mood in children and in acquiring new knowledge.

Survey results from the second group of tasks, show that preschool educators have good command of modern operating systems, and that they are trained to properly use the web and application software for planning and delivering the activities, which is confirmed 
by the second specific hypothesis that teachers consider to have sufficient personal competence in the use of computers in their work with preschool children.

Based on the analysis of the responses in the third group of tasks, it can be concluded that the third specific hypothesis is not confirmed because preschool educators believe that their IT training during initial education is not sufficient for the successful implementation of computer technology in their work with preschool children. Obtainedanswers indicate that they are not particularly satisfied with the quality of the IT curriculum. They feel that it is not at the level required by the modern society.It is evident that the results of the study demonstrate a significant gap between the digital competences educators consider they possess and what they think about the quality of IT training during their initial education. The disproportion of the results suggests that preschool educators acquired most of their digital skills and competences through various forms of informal education on their own.

Finally, the fourth specific hipothesis has not been confirmed as well. The reponses argue that the working conditions and the technical resources of the surveyed institutions are insufficient for the successful implementation of computer technologz and the delivery of the planned activities.

\section{ACKNOWLEDGMENTS}

We would like to express our gratitude to Mrs Jelena Antić, the director of "Danica Jaramaz" preschool institution in Kosovska Mitrovica, Mr Dragan Mitić, the director of "Sunce" preschool institution in Donja Gušterica and Mr Srđan Ristić, the director of "Pčelica Maja" preschool in Ropotovo for their assistance in the organization and implementation of research.

\section{Conflict of interests}

The authors declare no conflict of interest.

\section{REFERENCES}

Andevski, M. \& Arsenijević, J. (2011). Kompetencije vaspitača za upotrebu novih medija i tehnologija. U Grujić T (ur.). Kompetencije vaspitača za drušzvo znanja (25-34). Zbornik radova VSSS$O V, 4(2)$, Kikinda: Visoka škola strukovnih studija za obrazovanje vaspitača.

Anđelković, N. (2008a). Informaciona tehnologija u predškolskom vaspitanju i obrazovanju. Zbornik radova Tehnika $i$ informatika u obrazovanju,
$T I O, 8,65-70$

Anđelković, N. (2008b). Dete $i$ računar u porodici $i$ dečijem vrtiću. Beograd: Beoknjiga.

Creasey, J.,Jarvis, P., Berk, L. (1998). Play and social competence. In O. Saracho \& B Spodek (Eds.), Multiple perspectives on play in early childhood education (116-143). NewYork: SunyPress.

Kopas-Vukašinović, E. (2007). Kompjuter kao igračka. U Danilović, M. i Popov, S. (prir.), Tehnologija, informatika $i$ obrazovanje IV (772-777). Beograd: Institut za pedagoška istraživanja;Novi Sad: Centar za razvoj i primenu nauke, tehnologije i informatike, Prirodno-matematički fakultet

Rečicki, Ž., \& Girtner, Ž. (2002). Dete i kompjuter. Beograd: Zavod za udžbenike i nastavna sredstva.

Veličković, S. (2014). Edukacija vaspitača za primenu IKT u vrtiću. U (prir.). Uticaj interneta na poslovanje u Srbiji i svetu (375-378). Prva Međunarodna naučna konferencija Sinteza 2014. Beograd: Univerzitet Singidunum.

Žiropađa, Lj (2007). Dete i komjuter-očekivanja i strepnje roditelja. Nastava $i$ vaspitanje, 36(1), 66-75. 